\title{
SONJA TIERNAN
}

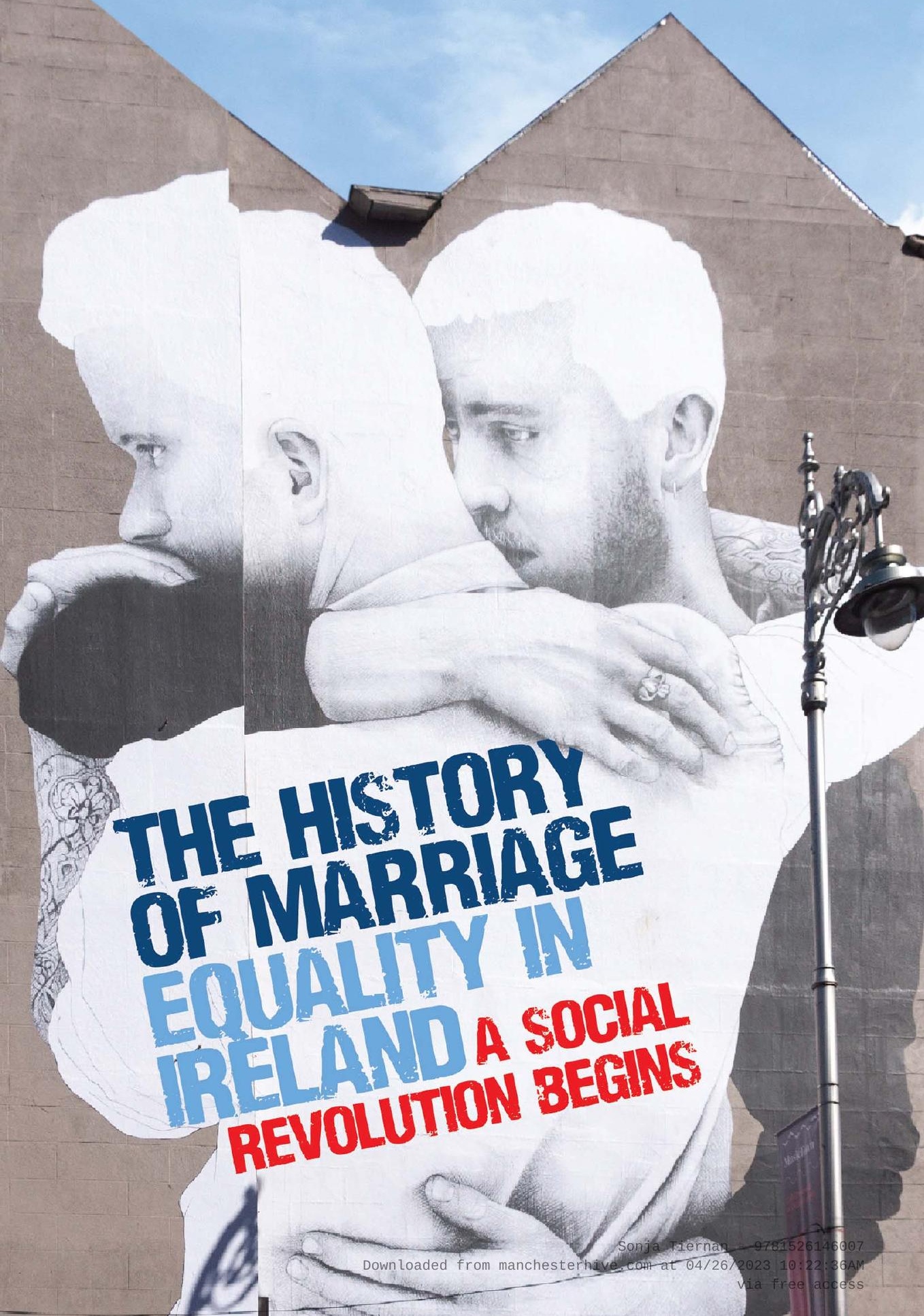




\section{The history of marriage equality in Ireland}

\section{MANCHESTER \\ 1824}

Manchester University Press 
Sonja Tiernan - 9781526146007

Downloaded from manchesterhive.com at $04 / 26 / 2023$ 10:22:36AM

via free access 


\section{The history of marriage equality in Ireland}

\section{A social revolution begins}

SONJA TIERNAN

Manchester University Press 
Copyright (C) Sonja Tiernan 2020

The right of Sonja Tiernan to be identified as the author of this work has been asserted by her in accordance with the Copyright, Designs and Patents Act 1988.

Published by Manchester University Press

Altrincham Street, Manchester M1 7JA

www.manchesteruniversitypress.co.uk

British Library Cataloguing-in-Publication Data

A catalogue record for this book is available from the British Library

ISBN 9781526145994 hardback

First published 2020

The publisher has no responsibility for the persistence or accuracy of URLs for any external or third-party internet websites referred to in this book, and does not guarantee that any content on such websites is, or will remain, accurate or appropriate.

Cover image: Mural by Joe Caslin, Dublin, Ireland. Part of the Yes Equality project. Photo by William Murphy. CC BY-SA 2.0

Cover design: riverdesignbooks.com

Typeset by

Servis Filmsetting Ltd, Stockport, Cheshire 